\title{
Przemiany formy tekstu kulinarnego (III-XIX w.)
}

Agnieszka M. Bąbel 
XAPIS Seria VI 2000

\section{Agnieszka M. Bąbel}

\section{Przemiany formy tekstu kulinarnego (III-XIX w.)}

I stnienie zjawiska zmienności konwencji gatunkowych i utartych form literackich jest prawdą banalną i powszechnie znaną, przynajmniej w odniesieniu do tak zwanej literatury pięknej. Temu samemu prawu podlegają też teksty z obszaru literatury użytkowej, do których niewątpliwie zaliczyć można przepis kulinarny. W owych metamorfozach odzwierciedlają się mniej czy bardziej wyraziście potrzeby i wybory estetyczno-ideowe danej epoki.

Charakterystyczną cechą dawnych przepisów kulinarnych był obezwładniający brak precyzji, który w gruncie rzeczy uniemożliwiał korzystanie $\mathrm{z}$ nich osobom pozbawionym uprzedniego doświadczenia kuchennego. Niedostatek informacji dotyczących konkretnego postępowania z produktami niezbędnymi do przyrządzenia danej potrawy, czasu jej gotowania lub pieczenia, a zwłaszcza proporcji używanych składników, daje się zaobserwować już w przepisach zawartych w De re coquinaria libri X. Niektóre zalecenia tej księgi, przypisywanej Markowi Gawiuszowi Apicjuszowi, mogą nieprzygotowanego czytelnika wprowadzić w osłupienie. Nie tylko bowiem nie spełniają one bowiem warunku dokładności, ale w dodatku wydają się złożeniem w obrębie jednego przepisu wskazówek na dwie zupełnie różne potrawy. Tak przynajmniej można wnosić z fragmentów w rodzaju: „W jaki sposób przyrządzić pieczony żołądek: obtocz go w otrębach, następnie włóż do roztworu soli i ugotuj" ${ }^{1}$ czy też „Cielęcinę lub wołowinę $\mathrm{z}$ porem albo $\mathrm{z}$ pigwą, albo $\mathrm{z}$ cebulą, albo $\mathrm{z}$ kolokazją przyrządzisz w ten sposób: weźmiesz sosu ze sfermentowanych ryb, pieprzu, asafetydy i trochę oliwy"2. W formie mniej jaskrawej jest to cecha tak typowa, iż przepisy, w których podaje się dokładne proporcje przy użyciu precyzyjnych miar i wag, naukowcy uważają za zaczerpnięte $z$ anonimowego greckiego podręcznika dla dietetyków ${ }^{3}$. W ogóle przez bardzo długi czas dokładność

\footnotetext{
' Apicjusz, O sztuce kulinarnej ksiag dziesięć, tł. i opr. I. Mikołajczyk, S. Wyszomirski, Toruń 1998, s. 177.

2 Ibid., s. 203.

${ }^{3}$ Ibid., s. 9-11.
} 
pozostaje przywilejem pism medycznych, co jest rzeczą naturalną, gdyż w tym szczególnym wypadku wszelkie zachwianie proporcji mogłoby okazać się nieobliczalne w skutkach. Oprócz rozmaitych zaleceń o charakterze typowo dietetycznym (np. środek ułatwiający trawienie i przeciw wzdęciom) przykładem takiego tekstu może być przepis na patinę z róż (prawdopodobnie rodzaj potrawy przygotowywanej w formie):

Patina $z$ róż: weźmiesz róże i oberwiesz płatki. Usuniesz z nich białe żyłki, włożysz do moździerza. Dolejesz sosu ze sfermentowanych ryb. Utrzesz. Następnie dolejesz do tego póttora cyathus [miara pojemności równa 0,045 litra] sosu ze sfermentowanych ryb, a otrzymany $z$ tego plyn przecedzisz przez sitko. Weźmiesz cztery móżdżki, oczyścisz je z błony i utrzesz osiem scripuli [scripulus — najmniejsza jednostka wagi równa 1,14 grama] pieprzu. Dolejesz otrzymanego wcześniej płynu i utrzesz. Potem wbijesz osiem jaj, dodasz półtora cyathus wina zwykłego i jeden cyathus wina $\mathrm{z}$ rodzynek, nieco oliwy. Następnie wysmarujesz patelnię tłuszczem i wstawisz ją do gorącego popiołu. Potem przełożysz do niej wyżej opisaną masę. Kiedy się ugotuje w gorącym popiele, potrawę posypiesz $z$ wierzchu mielonym pieprzem i podasz ${ }^{4}$.

W innych przepisach, zapewne zaczerpniętych $\mathrm{z}$ takich samych źródeł $\mathrm{i}$ dostosowanych do rzymskich realiów, pojawiają się rzymskie miary pojemności i ciężaru, takie jak acetabulum $(0,0681)$, calix (miara pojemności równa naszej szklance), cochleare $(0,0111)$, hemina $(0,271)$, quartarius $(0,14 \mathrm{l})$, sextarius $(0,54 \mathrm{l})$, dragma $(4,3 \mathrm{~g})$, libra $(327,4 \mathrm{~g})$, senuncia $(13,6 \mathrm{~g})$ i uncia $(27,2 \mathrm{~g}){ }^{5}$.

Dzieło przypisywane Apicjuszowi świadczy też o sile tradycji gastronomicznej. Żywotność niektórych wskazówek, dość przerażających pod względem higienicznym, może naprawdę zdumiewać. Oto rzymski przepis na poprawianie jakości mocno już woniejącego sosu, zwanego liquamen lub garum (sfermentowany sos z ryb), zawarty w księdze I Zapobiegliwy kucharz:

Jeśli sos ze sfermentowanych ryb będzie wydzielał przykry zapach, okadź dymem $z$ lauru i cyprysu puste odwrócone naczynie i wlej do niego sos ze sfermentowanych ryb, wystawiony wcześniej na świeże powietrze ${ }^{6}$.

Pomijając zalecenie wietrzenia nadpsutego produktu, dalekim echem odezwie się po wiekach ten przepis we wskazówkach Gospodyni doskonatej, która radzi,

Jak odświeżyć zepsute mięso? Tego rodzaju mięso należy wypłukać, namoczyć w czystej wodzie, potem odlać wodę i nalawszy je świeżą wodą, zagotować, odszumować i wrzucić do tej wody kilka rozżarzonych, ale nie dymiących

\footnotetext{
${ }^{4}$ Ibid., s. 89.

5 Ibid., s. 310.

${ }^{6}$ Ibid., s. 35.
} 
węgli drzewnych. Jeśliby to pierwsze odgaszanie węgli nie zupełnie pomogło, wtenczas należy do zmienionej raz jeszcze, a gotującej się wody, wrzucić ponownie czerwonych węgli. Po kwadransie wyjęte $\mathrm{z}$ tej wody mięso można już gotować i przyprawiać tak, jak świeże ${ }^{7}$.

Źródłem prawdziwej grozy dla czytelnika jest dopiero uświadomienie sobie, iż ta porada pochodzi z 1889 roku!

To, co $\mathrm{w}$ chwili obecnej kojarzy się z formą przepisu kulinarnego, w istocie wykształciło się późno, bo dopiero w XIX wieku. Jeśli bowiem porównać dwa przepisy — jeden pochodzący z tekstu stricte literackiego, jakim jest $\dot{Z}$ ywot czlowieka poczciwego, drugi zaś zaczerpnięty z Compendium ferculorum i powtarzany później przez osiemnastowieczne książki kucharskie — okaże się, że nie różnią się one wcale stopniem precyzji podawanych zaleceń. Oto Rej:

Nuż też ćwikiełki w piec namiotawszy a dobrze przypiekszy, nadobnie ochędożyć, w talerzyki nakrajać, także w faseczkę ułożyć, chrzanikiem, co najdrobniej ukrążawszy, przetrząsać, bo będzie długo trwała, także koprem włoskim, troszkę przetłukszy, przetrząsać, a octem pokrapiać, a solą też trochę przesalać; tedy to jest tak osobny przysmak, ani twoje limunije, bo i rosołek barzo smaczny, i sama pani ćwikła, bo już będzie i barzo smaczna, i barzo nadobnie pachnęła ${ }^{8}$.

Pomijając brak charakterystycznych dla pisarskiego stylu Reja deminutiwów, tekst z założenia profesjonalny, użytkowy, niewiele się od niego różni. W obu brak proporcji składników, czasu przygotowywania potrawy i wielu innych informacji niezbędnych dla osoby, która nie posiada wcześniejszego doświadczenia kulinarnego:

Potrawa w dobrej jusze albo po królewsku. Weź jarząbka albo kuropatwę, ptaszki albo gołąbki, kapłuna albo cielęcinę, albo co chcesz, wymocz, spuść w garniec, zasol, odwarz, odbierz, nacedź znowu tym rosołem, pietruszki włóż, a gdy dowiera wlej gąszczu, octu, słodkości, szafranu, pieprzu, cynamonu, rodzynek obojga, limonii, przywarz a daj na misę 9 .

Beztroska hojność w szafowaniu kosztownymi przyprawami wyraźnie wskazuje na barokowe pochodzenie przepisu. Trudność sprawiają też zapomniane już terminy, używane w kuchni staropolskiej na oznaczenie produktów i czynności, które należało wykonać, aby na koniec móc wyłożyć na misę „potrawę w dobrej jusze”. Jak komentuje to Elżbieta Kowecka, badaczka kultury materialnej wieku dziewiętnastego:

${ }^{7}$ Gospodyni doskonala..., nakł. i dr. Fr. Chocieszyńskiego, Poznań 1889, reprint Poznań 1990, s. 112.

${ }^{8}$ M. Rej, Żywot czlowieka poczciwego (uybór), Wrocław 1997, s. 100.

${ }^{9}$ E. Kowecka, W salonie i w kuchni, Warszawa 1984, s. 127. 
Rzecz oczywista, dzisiejszemu czytelnikowi trzeba wszystko tłumaczyć od początku, że jucha to sos, jarząbek to ptak z rzędu kuraków o wyjątkowo smacznym mięsie, kapłon to wykastrowany kogut, który dzięki temu zabiegowi doskonale się tuczył, „odwarz” znaczy: ugotuj, a „odbierz” — odcedź, „nacedź” znów - to zalej, a "gąszcz" w tym wypadku to zapewne bardzo gęsty sos z jarzyn (taką definicję przynajmniej znaleźliśmy w Kucharzu doskonatym z 1783 r. , podczas gdy słownik Karłowicza, Kryńskiego, Niedźwiedzkiego mówi, że to „rzecz gęsta, fusy, ustoiny, drożdże”); „słodkość” to zapewne rodzaj melasy z rozgotowanych buraków cukrowych lub jeszcze cukier trzcinowy, „rodzynki obojga” to rodzynki jasne i ciemne, „limonia” zaś to cytryna. Ale nawet $i$ teraz, gdy zrozumieliśmy znaczenie słowne przepisu, nie znamy żadnych proporcji. Ile tego wszystkiego mamy brać i w jakim stosunku? $\mathrm{Na}$ ile to osób danie? Jak długo trzeba je gotować? ${ }^{10}$

Z niedogodności, jakie stwarzała potencjalnemu czytelnikowi taka forma tekstu kulinarnego, zaczęli sobie rychło zdawać sprawę autorzy książek kucharskich. Aby dotrzeć także do czytelnika niewyspecjalizowanego, należało poświęcić zwięzłość na ołtarzu dokładności. Stąd na początku XIX w. ktoś ukrywający się pod kryptonimem J. S. (zapewne Jan Szyttler, reklamujący sam siebie jako ,jeden ze sławniejszych kucharzów europejskich”) zwraca się do czytelnika w swojej przedmowie do Kucharza doskonatego:

Wielu już w tej materii pisało, wykładając przysposobienie potraw do stołu, ale nikt prawie nie mógł $\mathrm{z}$ tych przepisów korzystać nie znalazłszy w nich dokładnego wyrażenia proporcji wchodzących artykułów do potraw, onych przysposobienia i stosownego uwarzenia, aby oczekiwanemu smakowi odpowiadały ${ }^{11}$.

W drugiej połowie XIX w. przepisy są już zupełnie inne. Doskonała gospodyni postępująca w myśl wskazówek Lucyny Ćwierczakiewiczowej w kuchni ma pod ręką termometr (w tych czasach używa się powszechnie 80-stopniowej alkoholowej skali Réamura), wagę i zegar. Istotna staje się temperatura wypieku ciast, czas pieczenia czy gotowania potrawy, wreszcie - proporcje używanych składników. Nic dziwnego więc, że popularna autorka zaopatruje swoje porady w rozdział Zamiana wagi na miarę zastosowana do codziennych kuchennych potrzeb, gdzie $z$ wyżyn swego doświadczenia udziela młodym i niedoświadczonym kucharkom praktycznych wskazówek:

Pomimo, iż w przepisach moich staram się wszystko bardzo dokładnie i wyraźnie oznaczyć, jednak dla ułatwienia gospodyniom nie mającym czasu lub cierpliwości ważenia każdego przedmiotu użytego do gotowania, a bez czego taka potrawa, a co najbardziej, ciasto lub legumina popsuć się mogą, podaję niniejszym zamianę funtów na miarę, co rzeczywiście łatwiej i prędzej się daje dopełnić.

\footnotetext{
${ }^{10}$ Ibid., s. 127-128.

"Ibid., s. 128.
} 
Funt cukru jest to pół kwarty dawnej polskiej, pół funta więc będzie kwaterka, a że mniej więcej każda zwyczajnej wielkości do herbaty używana szklanka lub filiżanka odpowiada kwaterce, szklanka więc duża pełna mączki cukrowej lub cukru tartego jest pół funta. Łyżka cukru równa się czterem łutom. Zupełnie ta sama zasada stosuje się do masła, którego kwarta jest dwa funty i łutów 8 , pół kwarty więc funt jeden i łutów 4, biorąc więc szklankę, mamy niezawodnie nie więcej, jak pół funta. Najlepiej jednak do masła mieć wymierzone dwa garnuszki; jeden półkwartowy, a drugi kwaterkowy, w szkle bowiem źle mierzyć na przykład klarowne masło gorące.

Łyżka masła równa się 4 łutom. Co do mąki przyjęto jest za zasadę, że garniec zawiera 5 funtów, ja jednak przekonałam się, że kwarta zawiera funt 1 i łutów 12 najmniej, to jest jeżeli jest strychowana, garniec więc ma funtów 5 i pół. U siebie w kuchni biorę pół kwarty czubate mąki za 3 ćwierci funta, czyli kwaterkę za 12 łutów, szklankę więc strychowaną brać można za 10 łutów. Najlepiej jednak do mąki i cukru mieć półkwartę i kwaterkę. Łyżka mąki równa się 2 łutom...

Jednak wszystkie te skomplikowane wyliczenia autorka kończy przezornym stwierdzeniem: „gdy idzie o większą ilość, zawsze lepiej użyć wagi" ${ }^{12}$. Ćwierczakiewiczowa zwraca też baczną uwagę na jakość produktów używanych do potraw (stąd liczne wskazówki dotyczące „poznawania dobroci” jaj, mięsa czy owoców), o czym zresztą mówi wprost w przedmowie do kolejnego (tym razem XX) wydania swoich słynnych 365 obiadów:

Uważam za właściwe dodać, że świeżość i wybór dobrego prowiantu jest pierwszym warunkiem dobrej kuchni, bo ze złych rzeczy nic dobrego wytworzyć nie można ${ }^{13}$.

Zatem — żadnych wskazówek dotyczących odświeżania zepsutego mięsa! Niezwykle istotna jest też jakość wody (na przykład do rosołu zaleca się używać „lepiej miękką, niż twardą"14 , rozróżnia się wodę rzeczną, studzienną i źródlaną - te dwa ostatnie gatunki wody, jako twarde, były najlepsze do sporządzania konfitur, gdyż owoce nie rozgotowywały się tak szybko), a także narzędzia kuchenne i rodzaj opału: „Rosół, bulion, a nawet każda zupa, do której wchodzi jakikolwiek kwas, powinna być gotowana w garnku kamiennym polewanym. W rondlu [żelaznym] gotuje się zbyt szybko i paruje zanadto, glina zaś będąc złym przewodnikiem ciepła, utrzymuje rosół w jednostajnem gotowaniu” 15 ; „Żadna pieczeń ani ciasto nie zrumieni się w piecu opalanym węglami" "16; gdy gotuje się owoce na konfiturę (cytryny, pomarańcze lub orzechy włoskie), aby zapobiec ich pękaniu, należy je gęsto „nakałać” szpilką

${ }^{12}$ L. Ćwierczakiewiczowa, Jedyne praktyczne przepisy... wedlug wydania z 1885 roku, Warszawa 1985, s. 332-333.

${ }^{13}$ L. Ćwierczakiewicz, 365 obiadów, Warszawa 1911, reprint Warszawa 1988.

${ }^{14}$ Ibid., s. 57.

15 Ibid.

${ }^{16}$ E. Kowecka, op. cit., s. 122 (L. Ćwierczakiewiczowa, Pieczeń cielęca, „Bluszcz” 1860, nr 20, Dodatek, s. 83). 
— koniecznie drewnianą ${ }^{17}$, nie metalową, zaś same konfitury „szumować w czasie smażenia dnem łyżki srebrnej" ${ }^{18}$. Łyżka cynowa zdecydowanie psuła smak wyrafinowanego produktu, a zbieranie tworzących się szumowin czubkiem zamiast „dnem” lub „tylcem” najwyraźniej sprzeciwiało się regułom sztuki.

Przepisy, zachwalane często przez samą autorkę jako tanie, proste i oszczędzające czasu, momentami zdają się potwierdzać tezę, iż każda kuchnia na odpowiednio rozwiniętym poziomie cywilizacyjnym ulega skłonności do perwersji. Na pięć przepisów dotyczących sporządzania konfitur z porzeczek, cztery nieodmiennie zaczynają się zaleceniem drylowania owoców („ziarna szpilką pojedyńczą powybierać”; „porzeczki wybrać z pestek”; „porzeczki wybrane z pestek”; „wybiera się z powierzchniej strony szpilką pestkę”), tylko jeden, przeznaczony widocznie dla profanów, nosi zachęcający nagłówek "Porzeczki bez druzgania"19. „Oszczędzającą czasu” konfiturę z włoskich orzechów do przybierania tortów przygotowuje się w sumie przez 27 do $30 \mathrm{dni}$, tyle bowiem zajmuje kolejne moczenie w miękkiej wodzie ${ }^{20}$, odsączanie, gotowanie i zalewanie najrozmaitszymi rodzajami syropu. Podobnie pracochłonny i wyrafinowany charakter ma konfitura z płatków róży, niezbędna jako nadzienie do prawdziwych pączków karnawałowych:

Funt obranych liści z róż dużych, cukrowych, oczyścić nożyczkami z żółtego proszku i wrzucić w dużą miskę z wodą twardą źródlaną, do której wlać poprzednio dwie łyżeczki kwaśnych kropli, znanych pod tą nazwą w aptekach, niech tak poleżą, aż się woda zrobi czerwonego koloru. Zrobić syrop z 6-ciu najmniej funtów cukru. Gdy cukier wyszumuje, wycisnąć ręką różę dobrze $z$ wody i wrzucić w syrop, łyżką srebrną ciągle w rondlu liście mięszając i rozcierając, aby się nie kawaliły, ale każdy oddzielnie smażył. Gdy róża nabiera przezroczystości, a syrop będzie dość gęsty, wlać znowu łyżeczkę kwaśnych kropli, lub wcisnąć 3 soczyste cytryny przez muślin, wylać konfiturę na salaterkę i w oknie lub w przewiewnym miejscu mięszać czyli przelewać łyżką, aż przestygną zupełnie. Każdy listek będzie osobno, a konfitura śliczna. $\mathrm{Na}$ dobrem wymięszaniu łyżką w chłodnym miejscu zależy piękność konfitury ${ }^{21}$.

\footnotetext{
${ }^{17}$ L. Ćwierczakiewiczowa, Jedyne praktyczne przepisy..., op. cit., s. 28.

18 Ibid., s. 46.

19 Ibid., s. 29-32.
}

${ }^{20}$ „Orzechy włoskie. Wziąć orzechy zielone, nakłuć gęsto szpilką drewnianą wokoło i moczyć w miękkiej wodzie dni 9 . Po 9 dniach nastawić w wodzie miękkiej, niech się gotują, aż zupełnie miękkie będą, tak, żeby z łatwością szpilka przechodziła; potem odlać na sito, żeby osiąkły; na funt orzechów wziąć 2 funty cukru, z połowy zrobić syrop niezbyt gęsty, włożyć w ten syrop kawałek cynamonu, goździków i zimnym syropem nalać orzechy, niech tak stoją trzy dni. Po trzech dniach wybrać orzechy na sito, do syropu dołożyć resztę cukru i wolnym zalać, niech tak postoją trzy dni. Po trzech dniach znów wybrać orzechy na sito, wygotować dobrze syrop, żeby był gęsty, i tym gorącym syropem polać orzechy, niech tak stoją; po 9 dniach, jeżeli orzechy od środka będą czarne, a skóra twardawa, to mają dosyć, jeżeli zaś nie, to jeszcze raz syrop odlać i wrzącym zalać orzechy. Ostudzić i za kilka dni układać w słoje" (ibid., s. 28-29).

2) Ibid., s. 35. 
Daleko w przeszłość odeszły już poczciwe zalecenia typu „weź jarząbka albo kuropatwę, albo co chcesz"! Teraz cytryny muszą być soczyste, wyciskać je należy przez muślin, a jakość konfitury uzależniona jest od cierpliwego mieszania srebrną łyżką w chłodnym i przewiewnym miejscu. Każdy element tego przepisu jest precyzyjnie określony i niezbędny w celu uzyskania zamierzonego efektu końcowego. Postępująca dokładność i konkretność kulinarnych wskazówek zbliża się do apogeum.

W parze z precyzją idzie także specjalizowanie się tekstu kulinarnego. Jest ono zdecydowanie mniej wyraziste - granice między zbiorem zaleceń gastronomicznych a poradnikiem gospodarstwa domowego wciąż bywają bardzo płynne. Jedyne praktyczne przepisy... Ćwierczakiewiczowej kończy Najlepsza zaprawa do posadzki rok najmniej trwajaca, z drugiej strony Stanisław Rewieński w Tece oszczędnych wskazówek między wyszczególnionymi w obszernym tytule Porzq̨lkami domowymi a Kosmetykami i pachnidlami umieszcza dział Napojów różnych przyrzq̨dzanie. (Co ciekawe, są to napoje wyłącznie procentowe — od likierów poprzez wódki aż do miodów). W XIX wieku zaczynają się jednak pojawiać coraz częściej wydawnictwa monotematyczne, jak choćby wspominany już Nowy, wyborny i najtanszy kucharz czyli sposób sporzqdzania najsmaczniejszych potraw $z$ kartofli tudzież użycie ich do różnych gospodarskich potrzeb. Ksiażeczka dla bogaczów równie jak dla ubogich użyteczna, zawierająa kilkaset sposobów wypróbowanych robienia $z$ kartofel różnych zup, jarzyn, potrawek, satat, legumin, wypiekanek $i$ innych przyrzqdzeń na stót; oraz użycie ich dla bydta, jako też do wyrobów piwa, wina, kawy, mydta, świec $i$ innych potrzeb domowych, wedlug wieloletnich doświadczeń przez przyjaciela ludzkości utożona.

Zbiory przepisów robią się coraz obszerniejsze. Z książek zawierających około stu (Kuchnia na sześć osób Pawla Tremo ${ }^{22}$ ) lub trzystu przepisów (Compendium ferculorum Stanisława Czernieckiego) zamieniają się w obszerne tomy, złożone z ponad tysiąca pojedynczych przepisów (Kucharka litewska czy 365 obiadów), uszeregowanych w grupy tematyczne. W osobnych rozdziałach znajdują się zupy, potrawy mięsne, rybne, dziczyzna, ciasta, desery, napoje. Książki tego typu coraz częściej zaczynają być zaopatrywane przez przezornych autorów w dyspozycje obiadów na cały rok, dostosowanych do pojawiających się produktów sezonowych, z wyszczególnieniem w menu dni postnych i świątecznych, a także — dążąc do zaspokojenia potrzeb jak największej ilości czytelników — podają dwie wersje tego samego posiłku, obliczone na możliwości finansowe odbiorcy: mniej i bardziej kosztowną, czyli „wystawną”. Pojawiają się książki kucharskie dla myśliwych i rekonwalescentów (Kuchnia mysliwska czyli na towach; Kuchmistrz nowy czyli kuchnia oddzielna dla osób ostabionych, w wieku podesztym, tudzież do zdrowia powracajacych $w$ proporcyi na jednę osobę Jana Szyttlera). Wskazówki dotyczące sporządzania przetworów umieszczane są w innych książkach niż menu obiadowe (zasady tej ściśle przestrzega Lucyna Ćwierczakiewiczowa w 365 obiadach i $w$ Jedynych praktycznych przepisach konfitur, różnych marynat, wędlin, wódek, likierów, win owocowych, miodów oraz ciast).

${ }^{22}$ Zob. S. Dubisz, O „urządzeniu” kuchni Króta JM Stanistawa Augusta, „Napis”, seria I, 1994, s. 113-134. 
Coraz większa precyzja przepisów i ich wyspecjalizowanie wychodzi naprzeciw potrzebom konkretnego odbiorcy.

Kto zaś miał być adresatem książki kucharskiej? Pierwotnie krąg odbiorców tego rodzaju tekstów był dosyć wąski, kierowano je mianowicie do kucharzy i ich pracodawców. Odpowiednio poinstruowany chlebodawca mógł kontrolować „ekspensę kuchenną” i wiedział, czego może od swojego kuchmistrza wymagać. Stąd też wczesne książki kucharskie, pochodzące z XVI i XVII w., zaczynały się nie wyszczególnieniem niezbędnego wyposażenia kuchni, lecz opisem idealnego kucharza:

Kucharz ma być ochędożny, z czupryną albo głową wyczesaną, podgoloną, rękami umytymi, paznokciami oberżnionymi, opasany fartuchem białym, trzeźwy, nieswarliwy, pokorny, chyży, smak dobrze rozumiejący, potrzeby do potraw dobrze znający i wszystkim usługujący ${ }^{23}$

— domaga się Stanisław Czerniecki we wstępie do swego Compendium ferculorum. Taki sposób rozpoczynania tekstu kulinarnego wpisuje się zresztą w tradycję piśmiennictwa gastronomicznego - słynna książka kucharza Piusa V, Bartolomeo Scappiego (Opera, Wenecja 1570) w pierwszej z sześciu części, na jakie jest podzielona, zawiera opis cech dobrego kucharza i kwalifikacji niezbędnych do wykonywania tego odpowiedzialnego zawodu.

Doskonale tłumaczy to zresztą brak szczególowych informacji w podawanych przepisach, bo profesjonalista, „potrzeby do potraw wszystkie znający”, nie musiał posiłkować się wskazówkami tego rodzaju, niezbędne wiadomości dotyczące proporcji i czasu przyrządzania potrawy czerpiąc po prostu $\mathrm{z}$ własnego bogatego doświadczenia.

Jeszcze wXVIII w. krạg czytelników użytkowych tekstów kulinarnych pozostawał bez zmian.

Na egzemplarzu Kucharza doskonatego... z francuskiego przettumaczonego $i$ wiela przydatkami pomnożonego przez Wojciecha Wielądka, pochodzącym z biblioteki pałacu w Nieborowie, widnieje następujący zapisek skreślony zapewne ręką Marty z Trębickich Radziwiłłowej: „R. 1783 die 4 X-bra w Warszawie u Grela kupiłam tę książkę, dałam za nią zł pol. 5. Uczyć kucharza Marcinka, bo niegodziwie jeść daje"24.

Dowodzi to oczywiście przeznaczenia tekstu - w sferze magnaterii, do której należeli Radziwiłłowie, traktowanego jako podręcznik fachowy. Wobec stosunkowo niewielkich nakładów i faktu, iż tylko bogatą szlachtę stać było na utrzymywanie kucharzy ze znakomitą praktyką i odpowiednim doświadczeniem, zdobywanym w renomowanych kuchniach dworów królewskich i magnackich, należy przypuszczać, że uboższy ogół kontentował się włas-

\footnotetext{
${ }^{23}$ M. Lemnis, H. Vitry, W staropolskiej kuchni i przy polskim stole, Warszawa 1979, s. 159.
}

${ }^{24}$ E. Kowecka, op. cit., s. 127. 
noręcznie sporządzanymi zapiskami, często przekazywanymi w spadku córce przez matkę. Zachowały się takie sylwy gastronomiczne jeszcze z XIX stulecia.

Rychło jednak kucharz przestaje być wyłącznym odbiorcą zbioru kulinarnych przepisów. $Z$ jednej strony wiąże się to ze wzrastająca pauperyzacją społeczeństwa, a co za tym idzie ze skłonnością do ograniczania licznych zastępów służby, które dotychczas żyły i pracowały w dworach i dworkach, z drugiej - ma niewątpliwy związek ze zmieniającą się pozycją kobiety, zwłaszcza w sferze gospodarczej i zarobkowej. XIX wiek zaczyna doceniać „gospodarstwo kobiece", do którego tradycyjnie zaliczano hodowlę drobiu, produkcję nabiału czy wyrób płótna, okazuje się bowiem, iż może ono przynosić niebagatelne dochody, zwłaszcza w momencie drastycznego zmniejszenia się zapotrzebowania na zboże (kwestia podatków akcyzowych i konfiskat majątków, zwłaszcza po 1864 r. na terenie Królestwa Polskiego). Efektem staje się również przyznanie pani domu, dotychczas raczej biernej, roli zarządzającego, od którego rozsądku, pracowitości i oszczędności uzależnione jest funkcjonowanie całego gospodarstwa. Dlatego też ogromna większość poradników i książek kucharskich tego okresu skierowana jest do kobiet - głównie ziemianek, posiadających własny ogród i obszerne gospodarstwo (Karolina Nakwaska, Dwór wiejski, dzieło poświęcone gospodyniom polskim, przydatne i osobom $w$ mieście mieszkajacym - cały drugi tom tej szacownej książki to Kuchnia wiejska). Ambicją epoki pozostaje jednak spełnianie zamówienia społecznego większej grupy czytelników - w tym wypadku czytelniczek — takie autorki jak Lucyna Ćwierczakiewiczowa kierują więc swoje teksty również do mieszkanek miast, starając się uczynić je jak najbardziej uniwersalnymi. Charakterystyczne, że przedmowy, jakimi Ćwierczakiewiczowa opatruje swoje książki, noszą tytuł Stówko do gospodyn ${ }^{25}$,nie zaś „do kucharzy”.

Wzrastające nakłady i wznowienia tych samych pozycji (starczy wspomnieć sukces wydawniczy 365 obiadów!) odzwierciedlają również zmiany w sferze rynku czytelniczego, który w XIX wieku ogromnie wzrasta. Nie tylko umiejętność czytania staje się coraz powszechniejsza, ale także lektura, zwłaszcza książek pożytecznych i służących samokształceniu, zaczyna cieszyć się społeczną akceptacją jako sposób spędzania wolnego czasu. Książki przestają być też artykułem luksusowym ze względu na wysoką cenę, są więc coraz częściej i chętniej kupowane.

O tym, jak dalece zmieniła się sytuacja w ciągu stulecia, może świadczyć tekst z początku XX wieku. Autorka popularnej książki kucharskiej użala się w przedmowie, skierowanej do łaskawego czytelnika:

Wiem z doświadczenia, że najczęściej u nas kupuje się książkę kucharską, jako komplet do wyprawy, aby była w domu i leżała na półce. Zagląda się do niej tylko od czasu do czasu, gdy na przyjęcie gości wypadnie sporządzić jakąś trudniejszą potrawę, lub przed świętami upiec torty i mazurki. Rzadko nawet słowo wstępne bywa czytane ${ }^{26}$.

${ }^{25}$ L. Ćwierczakiewiczowa, Jedyne praktyczne przepisy..., op. cit., s. 1.

${ }^{26}$ M. Ochorowicz-Monatowa, Uniwersalna ksiqżka kucharska, Lwów 1911, s. 2. 
Jak z powyższego widać, ambicja autorska jest rzeczą nienasyconą, nie wystarcza jej bowiem świadomość, że książka kucharska awansowała do pozycji niezbędnej części każdej panieńskiej wyprawy (o czym nie mogły przecież nawet marzyć teksty z początku XIX w.) — mało tego, pragnie jeszcze, aby dzieło było czytane $z$ uwagą i szacunkiem:

Jeśli jest czas na grę na fortepianie, śpiew, robótki, uprawianie sportów różnych, wizyty i zabawy, to niechże się znajdzie i na przestudiowanie książki kucharskiej, co z większą dla każdej kobiety będzie korzyścią, niż przeczytanie byle jakiej powieści sensacyjnej ${ }^{27}$.

$\mathrm{Z}$ kwestią projektowanego odbiorcy tekstu nierozerwalnie łączy się problem autokreacji autora. Owa kreacja nadawcy rysuje się wyraziście już w samym tytule, który stanowi przecież pierwszy element książki mogący zachęcić potencjalnego nabywcę do kupna produktu i prawdopodobnego adresata do przeczytania dzieła. W najstarszych polskich tekstach gastronomicznych i poradnikowych o kompetencji autora mają świadczyć jego szlacheckie koneksje, pełnione godności i tytulatura stałych chlebodawców. Zjawisko to można zaobserwować na przykładzie tytułu:

Compendium ferculorum albo zebranie potraw przez urodzonego Stanisława Czernieckiego J K. M. sekretarza, a Jaśnie Wielmożnego Imci Pana Aleksandra Michała Hrabi na Wiśniczu i Jarosławiu Lubomirskiego, wojewody krakowskiego, sandomirskiego, zatorskiego, niepołomskiego, lubaczewskiego, ryckiego etc. etc. starosty kuchmistrza ad usum publicum napisane.

Podobnie rzecz się ma z pierwotnym tytułem dzieła Jakuba Kazimierza Haura, który brzmi:

Ekonomika ziemiańska generalna, punktami partykularnymi, interrogatoryjami gospodarskimi, praktyką miesięczną, modeluszami abo tabulami arytmetycznymi objaśniona, panom dziedzicznym, arendarzom, ekonomom, aktentom, urzędnikom, pisarzom prowentowym i wszystkim w pospolitości dóbr ziemskich dozorcom pożyteczna i potrzebna, przez urodzonego Jakuba Kazimierza Haura, pisarza i superintendenta wszelkich intrat Jaśnie W. Imc. kasztelana wojnickiego, wielkorządcy krakowskiego, drohobyckiego, złotoryjskiego i barwalskiego etc., starosty ekonomii samborskiej, wielickiej i bocheńskiej karbaryjej administratora, sporządzona.

Praktyka grzania się w świetle cudzej wspaniałości i przydawania sobie splendoru poprzez wymienianie godności i ziem dziedzicznych patrona wydaje się bardzo charakterystyczna dla mentalności sarmackiej klienteli, o której powyższe przykłady mówią więcej niż o samej

${ }^{27}$ Ibid., s. 3. 
zawartości dzieł. Jak widać, zaufanie odbiorców do sekretarza Jego Królewskiej Mości albo superintendenta wszelkich intrat było na tyle duże, iż barokowa tytulatura stanowiła wystarczający dowód na profesjonalizm i doświadczenie autora ${ }^{28}$.

Na przeciwnym zgoła biegunie stoją dziewiętnastowieczne teksty anonimowe (jak choćby wspomniany Nowy, wyborny i najtańszy kucharz poświęcony potrawom i sposobom produkcji najrozmaitszych "potrzeb domowych" z kartofli, a sygnowany skromnie przez „przyjaciela ludzkości"), lub podpisywane jedynie inicjałami. Co prawda były to kryptonimy dość przejrzyste, pozwalające od razu domyślić się pod maską "J. S. — jednego ze sławniejszych kucharzów europejskich" Jana Szyttlera, litewskiej wyroczni kulinarnej w pierwszej połowie XIX w. , nie mówiąc już o „Lucynie C., autorce 365 obiadów”. W tej przedziwnej skromności można dopatrywać się cech naiwnej kokieterii lub pragnienia ukrycia się w cieniu własnego dzieła na wzór anonimowych średniowiecznych mistrzów. Literatura użytkowa epoki pozytywizmu obfituje też w utwory nieznanego autorstwa, które swoim nazwiskiem firmuje jedynie wydawca (Gospodyni doskonała... wydana nakładem i drukiem Fr. Chocieszyńskiego). Niezależnie od tego, czy nadawca jest postacią anonimową, czy przedstawia się czytelnikowi konkretnym imieniem i nazwiskiem, zawsze posiada pewien zestaw stałych, wyrazistych cech, które pozwalają nieomylnie rozpoznać w nim pozytywistycznego twórcę literatury użytkowej:

W te wszystkie książki wpisany jest autor: kompetentny i wiarygodny, doświadczony, z praktyką życiową i zawodową w renomowanych domach lub firmach, zdolny i pomysłowy (sam wymyśla przepisy), otwarty i oczytany (korzysta też $z$ doświadczenia innych), rzetelny (sam wszystko wypróbował), nowoczesny i aktualny (opiera się na naukowych zdobyczach), elastyczny i uniwersalny (zna potrzeby wszystkich czytelników i umie je uwzględnić), doskonały fachowiec (gwarantowana jakość przepisów), życzliwy (dobrze radzi) ${ }^{29}$.

Tytuł nadal obliczony jest na przyciaganie uwagi potencjalnego czytelnika, ale obecność autora nie ujawnia się w nim tak wyraziście, jak w tekstach siedemnastowiecznych. Widać tu oczywiście dyskretną sugestię wszechstronności i uniwersalności nadawcy, co wyraża się w zawartości strony tytułowej, stanowiącej niekiedy dokładne odbicie spisu treści. Za przykład niech posłużą: Kucharka litewska zawierająca przepisy gruntowne i jasne, wtasnym doświadczeniem sprawdzone, sporzqdzania smacznych, wykwintnych, tanich i prostych rozmaitych rodzajów potraw tak mięsnych, jak i postnych oraz ciast, legumin, lodów, kremów, galaret, konfitur i innych przysmaków deserowych, tudzież rozlicznych zapraw aptecznych, konserw i rzadszych specjatów z przydaniem na początku ksiażki doktadnej dyspozycji stotu przez W. A. L. Zawadzkq lub Teka oszczędnych wska-

\footnotetext{
${ }^{28}$ Należy jednak zaznaczyć, iż późniejsze wydania tekstu Haura pod zmienionymi tytułami (Ziemiańska generalna oekonomika... czy Skład abo skarbiec znakomitych sekretów oekonomii ziemiańskiej... nie dręczą już czytelnika w takim stopniu rozbudowaną tytulaturą szlachecką, co może również stanowić swoisty znak czasu.

${ }^{29}$ E. Ihnatowicz, Literacki siviat rzeczy, Warszawa 1995, s. 119.
} 
zówek, zawierająa: Pranie bielizny $i$ wszelkich materyj; bielenie ptótna $i$ innych przedmiotów. Czyszczenie najróżniejszych rzeczy, Wywabianie plam. Farbiarstwo i farbowanie. Pokosty i lakiery, atrament, tusz, szuwaks, smarowidla, kity, kleje. Sto różnch sposobów używanych w gospodarstwie domouym. Porzq̨dki domowe. Napojów różnych przyrzqdzanie. Kosmetyki i pachnidla. Tępienie szkodliwych zwierząt $i$ owadów. Przepisy hygieniczne i lecznicze dla ludzi i zwierząt. $Z$ najlepszych źródet opartych na nauce i doświadczeniu zebrat i w porzadek ulożyt Stanistaw Rewieński.

Dbałość o odpowiednią formę reklamy wyraża się między innymi w staranności, z jaką autorzy książek kucharskich pilnują zaznaczania na okładce i pierwszej stronie numeru porządkowego kolejnego wydania, często zaopatrując je w specjalną dla każdej nowej edycji przedmowę ${ }^{30}$. Zdarza się również, iż w przewidywaniu następnego wydania autor zwraca się do czytelników z prośbą o współpracę, jak czyni to Stanisław Rewieński, drukując pod tytułem swego poradnika apel:

Nabywcy książki niniejszej proszeni są uprzejmie o udzielenie jej wydawcy uwag i sposobów wypróbowanych, do umieszczenia przy nowym wydaniu Teki.

Taka postawa, zakładająca dialog z odbiorca, zmusza również do traktowania go w inny sposób, niż miało to miejsce w początkach polskiego piśmiennictwa kulinarnego. W Compendium ferculorum Czerniecki zwraca się do czytelnika, używając bezceremonialnej formy drugiej osoby - wszystkie polecenia wydawane są w trybie rozkazującym („weź”, „przewarz”, „nacedź" itp.). Teksty dziewiętnastowieczne zdecydowanie wybierają w takim wypadku formy bezosobowe, stąd polecenia przybieraja postać bezokoliczników (u Ćwierczakiewiczowej czy Zawadzkiej jest już prawie zawsze „wziąść”, „obrać”, „ugotować” itd.). Można łączyć to zjawisko ze stanowcza zmianą adresu czytelniczego. W książkach staropolskich do kucharza, czyli osoby zależnej, należącej do służby, a więc znajdującej się w pozycji niższej lub co najwyżej równej nadawcy tekstu, można było przemawiać bez szczególnego skrępowania. Do zamożnej i niezależnej pani domu należało się już zwracać z większym szacunkiem. Coraz częściej też autor przemawia jako „my”, jakby w imieniu jakiejś społeczności, co staje się rychło powszechną praktyką książek kucharskich. Na wypowiadanie się w formie ,ja” mogą pozwolić sobie jedynie niekwestionowane autorytety w rodzaju Lucyny Ćwierczakiewiczowej (,ja jednak przekonałam się, że jedna kwarta zawiera funt 1 i łutów 12 najmniej”). Większość autorów preferuje jednak zdecydowanie wypowiedzi w liczbie mnogiej.

\footnotetext{
${ }^{30}$ Owa dbałość o wlasne interesy spowodowała, iż natychmiast po błędnej uwadze Bolesława Prusa, zamieszczonej w Kronice tygodniowej „Kuriera Codziennego” nr 140 z 22 maja 1887, Lucyna Ćwierczakiewiczowa wysłała do redakcji list z reklamacja, wyjaśniając iz „ $Z$ powodu wzmianki uczynionej we wczorajszej Kronice tygodniowej Prusa oświadczam, że nie dwunasta, lecz czternasta edycja 365 obiadów wyszła już w roku zeszłym; obecnie puścilam w świat dwunaste wydanie Jedynych praktycznych przepisów smażenia konfitur itd.". Redakcja uznała konieczność dokonania sprostowania i poprzedziła je komentarzem: „Czyniąc zadość słuszności i pragnąc nie utracić lask p. Lucyny Ćwierczakiewiczowej, umieszczamy skwapliwie następujące jej pismo...” (zob. B. Prus, Kroniki, t. 10, oprac. Z. Szweykowski, Warszawa 1960, s. 357).
} 
Różnicę między beztroską i subiektywną liczbą pojedynczą a autorytatywną liczbą mnogą w najbardziej klarowny i pełen wdzięku sposób przedstawia Anthèlme Brillat-Savarin w swoim wstępie do Fizjologii smaku:

Kończę uwagą ważną i dlatego zachowałem ją na ostatek. Kiedy piszę i mówię ja w liczbie pojedynczej, oznacza to rozmowę z czytelnikiem; może zastanawiać się, dyskutować, wątpić, a nawet śmiać się. Ale kiedy zbroję się w niebezpieczne my, pouczam; trzeba się podporządkować ${ }^{31}$.

Dydaktyzm i utylitaryzm wchodzą w skład stałych i niezmiennych cech literatury użytkowej. Pragnąc kształtować upodobania i poglądy czytelników, chętnie korzysta ona z przywileju pouczania, przysługującego zbiorom pożytecznych informacji. Z drugiej strony jednak ten typ piśmiennictwa w bardzo dużym stopniu zależny jest od popularności na rynku czytelniczym, zatem stara się wychodzić naprzeciw potrzebom swoich odbiorców. Ponieważ zaś te potrzeby i gusta zmieniają się z upływem czasu, teksty poradnikowe czy kulinarne pochodzące $z$ różnych wieków będą bardzo często odzwierciedlać ideologię i estetykę swojej epoki. W siedemnastowiecznym Compendium ferculorum pióra Stanisława Czernieckiego można znaleźć wiele przepisów świadczących o ukształtowanej przez barok mentalności autora i czytelników, a także konsumentów potraw, sporządzonych wedle porady znakomitego kuchmistrza Lubomirskich. Cytowany już poprzednio przepis na „potrawę w dobrej jusze albo po królewsku”, który zakłada oblanie ugotowanego mięsa sosem z „gąszczu, octu, słodkości, szafranu, pieprzu, cynamonu, rodzynków obojga, limonii”, co najprawdopodobniej nie do rozpoznania zaciera jego naturalny smak, dowodzi sarmackiej orientalizacji gustów i upodobania do przepychu. Masa kosztownych przypraw, niezbędna do właściwego przygotowania potrawy, daje pochlebne świadectwo zamożności i obyciu gospodarza. Barokowe upodobanie do konceptów, poczytujące sobie za najważniejszy cel wprawienie odbiorcy w zdumienie i podziw, dobrze ilustrują przepisy takie, jak ten na „kuropatwy z ryb słonych":

Szczupaka słonego ochędoż pięknie. Mięso od skóry i kości odbierz, usiekaj. Wlej oliwy, chleba tartego, cebulę pieczoną usiekaj, daj pieprzu, cynamonu, rodzynków drobnych, cukru. Zmieszaj to wszystko pospołu i formuj w ręku ptaki jakie chcesz albo umiesz. Spuszczaj w kocieł wody gorącej, a potem natknij migdałami wzdłuż krajanemi, albo pinelami [orzeszkami pinii], potrząsaj mąką i puszczaj na gorące masło albo oliwę albo olej, a natkawszy skrzydełkami kuropatwimi albo takimi, jakie uformowałeś, ptaki, jeżeli chcesz, daj sucho, albo sapor [sos] jaki zapraw ${ }^{32}$.

\footnotetext{
${ }^{31}$ A. Brillat-Savarin, Fizjologia smaku albo medytacje o gastronomii doskonatej, wyb. i opr. W. Zawadzki, t1. i wst. J. Guze, Warszawa 1975, s. 15-16.

${ }^{32}$ K. Bockenheim, Przy polskim stole, Wrocław 1999, s. 194.
} 
Tego typu ingerencje w naturę - nadawanie ptakom kształtu ryb i odwrotnie, tworzenie zgoła mitycznych stworzeń typu smoków czy gryfów $z$ niewinnego pieczystego - w owym czasie dobrze świadczyły o kunszcie kucharza i pozwalały mu się wznosić na wyżyny sztuki gastronomicznej. Niekiedy w pogoni za zadziwiającym konceptem tracono $z$ oczu cel główny, forma przytłaczała treść i pracowicie przyrządzona potrawa nie nadawała się w ogóle do spożycia, stanowiąc jedynie efektowną dekorację stołu. Taką funkcję spełniał bez wątpienia „kapłon we flaszy”, który to przepis Czerniecki pomieszcza między swymi słynnymi „sekretami kuchmistrzowskimi":

Weźmi kapłona dworowego, ochędoż pięknie, zdejmi skórę z niego całkiem tak ostrożnie, żebyś dziury najmniejszej nie uczynił, a członki, z których się skóra zdją́ nie może, poprzerzynaj, żeby przy skórze zostały. Włóż tę skórę w flaszę taka, w której będzie dziura w śrubie, żebyś trzy palce włożył, trzymaj tę przerżniętą skórę w dziurze. Weźmi źóttków szesnaście, rozbij, przydaj trochę mleka, zapraw jako chcesz, wlej łoju w tę skórę $\mathrm{z}$ kapłona trzymając, a zaszyj i puść flaszę. Wody wlej pełną flaszę, zasol a zaśrubuj albo pęcherzyną zawiąż. Włóż w kocioł wody, warz. Gdy się ociągnie, to jajka z mlekiem rozedmą kapłona tak, że się będzie każdy dziwował, jako tam tego włożono kapłona, gdy go dasz z flaszą na stól, a kto tego nie wie, nie będzie bez podziwienia wielkiego ${ }^{33}$.

Pragnienie wywołania "podziwienia wielkiego” u biesiadników usprawiedliwia zużycie dla tej sztuczki, bardziej iluzjonistycznej niż kulinarnej, szesnastu jaj $\mathrm{i}$ „kapłona dworowego”. Nie są to wprawdzie wielkie ekspensa w porównaniu z sumami, jakie wydawano na egzotyczne przyprawy, częstokroć sypane całymi garściami do potraw bez sensu i umiaru, lecz wystarcza, aby w czytelnikach $\mathrm{z}$ bardziej racjonalnej epoki wzbudzić uczucie zgrozy.

Autorzy tekstów kulinarnych z okresu pozytywizmu wyznaczyli sobie zupełnie odmienne priorytety. Naczelną wartością stało się odżywianie w sposób zdrowy i rozsądny, poparty częstokroć wskazaniami medycznymi, stąd też hojne dozy pieprzu i szafranu bezpowrotnie znikają z polskiej kuchni, przenosząc się w przeszłość kontuszy i konfederatek. Starano się pogodzić te zalecenia z przemożnym nakazem oszczędności, dyktowanej tak przez szlachetne uczucia patriotyczne, jak i przez trzeźwą ocenę własnych zasobów finansowych. Kuchnia ma stać się tania (przymiotnik tak częsty w tytułach i przy poszczególnych poradach, z natrętną wręcz częstotliwością szturmuje do świadomości czytelnika). Najlepiej byłoby wykorzystywać w niej produkty sezonowe i kupowane na miejscu, co zapewnia ich świeżość i niską cenę. Jeżeli zaś znajdą się odbiorcy rozmiłowani w kosztownych specjałach zagranicznych, przezorny autor zaproponuje im wówczas „kapary domowe”, sporządzane z gotowanych, solonych i zalewanych aromatycznym octem nasion młodej nasturcji, „można brać także do tego pączki z kwiatu, zwanego u nas kniatem, albo też bzu czarnego (sambucus nigra) ${ }^{334}$, albo też

\footnotetext{
${ }^{33}$ Ibid.

${ }^{34}$ Gospodyni doskonala, op. cit., s. 124.
} 
„kawior domowy”, przygotowywany z ikry szczupaka, który ,jest może nie tak smaczny i thusty, jak z jesiotra, lecz kolorem swoim złotawym do jedzenia zachęca i zaleca się, ponieważ nie jest kosztownym" "35. Nawet gospodyni tej miary, co Lucyna Ćwierczakiewiczowa, aprobuje istnienie tego rodzaju imitacji kulinarnych, przeznaczonych zapewne dla snobistycznych biesiadników. Czymże bowiem innym, jak nie podróbką, jest „indyjska konfitura naśladująca imbir", którą przyrządza się co prawda dość pracochłonnym sposobem, lecz za to oszczędza się na wydatkach domowych?

Wziąwszy naszą zwykłą banię [dynię] jeszcze niedojrzałą, można mieć z niej konfiturę, naśladującą do złudzenia smak i pozór imbiru. Wykroiwszy mięsistą część bani niezupełnie jeszcze dojrzałej, kraje się ją w kawałki, kształt podługowatych korzeni mające, i gotuje do połowy w wodzie zimnej, po czym wykłada na sito dla osiąknięcia, co gdy nastapi, układa się je na misce polewanej, każdy kawałek mocno obsypując bardzo miałko utłuczonym białym pieprzem i imbirem; przykrywszy na noc zostawić. Nazajutrz robi się syrop z lodowatego cukru, biorąc go dwa funty na funt bani, którą polać ciepłym syropem, na drugi dzień syrop przez sito lub gruby muślin przecedzić dla sklarowania, i dodawszy jeszcze funt zwyczajnego w najlepszym gatunku cukru, znów syrop na wolnym ogniu przegotować i gorącym polać banię — powtarzając to kilka razy, póki syrop nie będzie gęsty. Wtedy wrzucić banię na pięć minut w syrop gorący, zagotować raz i ułożoną banię w słoiki zalać przecedzonym syropem, a po wystygnięciu zawiązać słoje jak zwykle rozmiękczonym w zimnej wodzie papierem albuminowym, i jak wszytkie konfitury, w chłodnym a suchym miejscu przechować. Ta konfitura dobrze zrobiona może trwać lat kilka, czym starsza, tym lepsza ${ }^{36}$.

Jak widać, poczyniona inwestycja opłaci się, jeśli produktom najwyższej jakości będą towarzyszyć staranność i profesjonalizm gospodyni. Racjonalne podejście do przepisu, staranne rozważanie zysków i strat, szacunek dla fachowych umiejętności, warunkujących powodzenie zamierzonego przedsięwzięcia - wszystko to jest bardzo typowe dla tekstu pozytywistycznego!

W ogóle książka kucharska zrobila wtedy karierę jak nigdy dotąd. Dobrze się to mieści w klimacie epoki pozytywizmu zalecającej samokształcenie, bogatej w poradniki, samouczki, kodeksy postępowania i piśmiennictwo fachowe ${ }^{37}$.

Pozytywistyczny awans tekstu kulinarnego, a razem z nim całej literatury użytkowej, można łączyć ze wzrastająca popularnością takich gatunków literackich, jak powieść lub felieton. Dotychczas pogardzane, przeznaczane dla czytelników o mało wyrobionym guście,

\footnotetext{
${ }^{35}$ Ibid., s. 118.

${ }^{36}$ L. Ćwierczakiewiczowa, Jedyne praktyczne przepisy..., op. cit., s. 22-23.

${ }^{37}$ E. Ihnatowicz, op. cit., s. 118.
} 
żądnych sensacji i łatwej rozrywki, raptownie okazują się nieocenionym instrumentem, służącym do kształtowania opinii publicznej i przekazywania społeczeństwu własnego systemu wartości. Jeszcze raz sprawdza się słuszność Horacjańskiej zasady „Uczyć — bawiąc”. Literatura użytkowa, $z$ natury swojej przesiąknięta dydaktycznością i utylitaryzmem, nie potrzebuje osłody dowcipu, aby się dobrze sprzedawać. Tak samo jednak, jak czyni to powieść pozytywistyczna, książka kucharska będzie zabiegać o jak największe grono odbiorców.

Dziewiętnasty wiek jest też okresem krystalizowania się nowych form literackich i kształtowania się konwencji gatunkowych. To prawda zbliżona niemal do banału, iż istnienie konwencji stanowi zarazem pokusę do jej lamania. Stąd też coraz bardziej wyrazisty podział na obiegi czytelnicze i poziomy literackie sprzyja pojawieniu się takich zjawisk, jak aluzje, prowokacje bądź też po prostu żarty literackie ${ }^{38}$. Na rynku książki tekst kulinarny $\mathrm{i}$ tomik poetycki podlegają takim samym prawom popytu i podaży, w świecie krytyki literackiej nie są jednak traktowane równorzędnie. Ta coraz wyraźniej zarysowująca się świadomość znajduje odzwierciedlenie w podejmowanych przez pozytywistów próbach dowartościowania czy wręcz uwznioślenia literatury użytkowej, a także w częstych i różnorodnych sposobach nawiązywania do tekstu gastronomicznego $w$ toaście, powinszowaniu, eposie, powieści, liście czy felietonie, których przykładów można szukać w obrębie całego stulecia.

Może więc warto potraktować ksiażkę kucharską i poradnik gospodarstwa domowego jako barwny i ciekawy aneks, pozwalający na dostrzeżenie lekceważonych bądź w ogóle ignorowanych obszarów literatury danej epoki.

\footnotetext{
${ }^{38}$ Takie igraszki poetyckie stawały się często udziałem nie byle jakich autorów - starczy przypomnieć niedokończony poemat epicki mlodego Mickiewicza Kartofla. Poemko we czterech pieśniach (1819 r.), którego bohaterami są „ziemlanka”, jej odkrywcy i propagatorzy - klasycystycznej epice heroicznej przeciwstawia się tu na pół serio, pół żartobliwie apologię pracy (zob. A. Witkowska, R. Przybylski, Romantyzm, Warszawa 1999, s. 241-242).
} 